\title{
Source credibility as "information subsidy": Strategies for successful NGO journalism at Mexican human rights NGOs
}

\section{Ella McPherson}

To cite this article: Ella McPherson (2016) Source credibility as "information subsidy":

Strategies for successful NGO journalism at Mexican human rights NGOs, Journal of Human Rights, 15:3, 330-346, DOI: 10.1080/14754835.2016.1176522

To link to this article: http://dx.doi.org/10.1080/14754835.2016.1176522

$$
\begin{aligned}
& \text { (c) } 2016 \text { The Author(s). Published with } \\
& \text { license by Taylor \& Francis. (C) Ella } \\
& \text { McPherson. }
\end{aligned}
$$

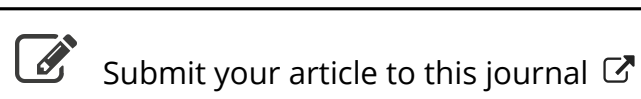

Џll Article views: 103

Q View related articles $\sqsubset$

View Crossmark data ¿ 


\title{
Source credibility as "information subsidy": Strategies for successful NGO journalism at Mexican human rights NGOs
}

\author{
Ella McPherson \\ University of Cambridge
}

\begin{abstract}
This article draws on Gandy's (1982) influential concept of "information subsidies" to examine strategies Mexican human rights NGOs employ to get their information into the news. By building their credibility as sources - through interpersonal relationships with journalists, through authority with human rights leaders, and through associations with NGO networks - NGOs provide a verification subsidy that shortens the time journalists need to evaluate the sources of their information. By playing to NGOs' strengths, namely their symbolic and social capital, this type of information subsidy holds promise for pluralism and accountability in the public sphere. This promise varies, however, according to what kind of pluralism we mean: namely, pluralism vis-à-vis the field of power, pluralism within the field of human rights NGOs, and pluralism of access to human rights accountability. It also varies according to the resources of the NGO in question, which affect the NGO's ability to demonstrate credibility and thus to provide information subsidies. The article's focus on the information subsidies provided by subordinate journalistic sources, particularly those that address information values about sources rather than about content, as well as on the centrality of credibility in communication across fields, further develops these concepts in media sociology.
\end{abstract}

\section{Introduction}

In theory, human rights nongovernmental organizations (NGOs) and news outlets interested in journalism that supports democracy should be efficient collaborators. After all, both are interested in pluralism, namely increasing the variety of voices in the public sphere. Both are also interested in holding power to account - news outlets in their watchdog role and human rights organizations in their drive to hold governments and other bodies to account for human rights violations. In practice, however, this collaboration is fraught. One way of understanding these tensions is as arising from the meeting of distinct logics (e.g., Cottle and Nolan 2007; Fenton 2010; Waisbord 2011; Powers 2014). After Thompson (e.g., 2010) and Bourdieu (e.g., 1983), we can think of a particular logic as the rules, explicit and implicit, that govern success in a particular field and thus the practices in that field. Rules about the value and use of information are central

CONTACT Ella McPherson em310@cam.ac.uk Department of Sociology, University of Cambridge, Free School Lane, Cambridge CB2 3RQ, UK.

This is an Open Access article distributed under the terms of the Creative Commons Attribution License (http://creativecommons.org/licenses/ by/4.0/), which permits unrestricted use, distribution, and reproduction in any medium, provided the original work is properly cited.

(c) 2016 Ella McPherson. Published with license by Taylor \& Francis. 
to the logics of both the journalistic field and the human rights NGO field, though these rules differ across the two fields. Gandy's (1982: 8) influential concept of information subsidies - namely, "efforts to reduce the prices faced by others for certain information, in order to increase its consumption" - is useful for understanding practices that aim to communicate across fields and therefore to bridge information logics.

A significant theme in the literature on the NGO-media relationship is the critique of the information subsidies NGOs must provide to attract attention in the context of commercializing journalistic logics. This critique is important and troubling, but it is not one that human rights NGOs can do much about except lament. As the largely dependent partner in the NGO-media relationship, it is unavoidable that NGOs are sensitive and responsive to the information-related needs and wants of news outlets, including their increasingly commercial imperatives. In contrast to the above critique, which focuses on discord between the information logics at NGOs and at news outlets, this article, by drawing on my media ethnography of human rights reporting in Mexico, turns to areas of accord. ${ }^{1}$ My argument is that information subsidies that play to the strengths of NGOs' logics while also following the rules of news outlets' information logics create a win-win scenario for these two fields as well as for the broader goals of pluralism and accountability they share. These information subsidies form part of the trend towards NGO journalism, or the adoption of journalistic values and practices by the NGOs who increasingly supply our news (Powers 2015a; Wright 2015).

Rules about the value of information identify characteristics that make the information valuable for activity in the field in question; hence, news values are part of journalistic logics (Waisbord 2011). These information values are divisible into those related to the information's content and those related to the information's source (McPherson 2015a). Information subsidies can thus subsidize practices related to the information's content, such as locating, evaluating, and shaping it. The can also subsidize practices related to the information's source, namely evaluating the source according to valued characteristics. The existing literature on information subsidies predominantly addresses the former and, concerning NGO journalism specifically, raises the aforementioned critique of the provision of commercialized content. In contrast, in this article, I largely address the latter - and particularly strategies that facilitate the evaluation of the source in question's credibility, which we can think of as a type of verification subsidy. ${ }^{2}$

As I explain in a subsequent section of this article, the symbolic capital (Bourdieu 1993) of credibility is central to the logics of human rights NGOs and of news outlets; NGOs' demonstration of their credibility as sources can therefore be an effective subsidy for information evaluation across these fields. I identify three strategies deployed by my informants at human rights NGOs in Mexico for building source credibility with journalists: credibility in interpersonal relationships, credibility via authority, and credibility via networks. These are all underpinned by the demonstration of credibility via performance over time. As credibility, or the ability to be believed, is a relational characteristic built between the seeker and the evaluator of credibility, it also relies on other core characteristics of NGOs' logics: their emphasis on solidarity and their related experience with networking social capital.

One of the most analytically useful aspects of the information-subsidy concept is that, as an economic metaphor, it highlights the connection between the ability to provide information subsidies and the possession of other forms of capital - and thus between pluralism and power. Accordingly, I argue that the information subsidy of source credibility, which draws on NGOs' symbolic and social capital, influences three types of pluralism: the 
pluralism of human rights NGOs in the public sphere vis-à-vis other sources; the pluralism among human rights NGOs in the public sphere; and the pluralism of access to public accountability, a fundamental aspect of the "naming and shaming" (Human Rights Watch 2013) mechanism of human rights. Though, overall, human rights NGOs' information subsidies derived from demonstrations of source credibility hold promise for pluralism and accountability in the public sphere, NGOs' ability to provide such subsidies is unequal and maps onto the general distribution of power amongst them.

\section{The relationship between human rights NGOs and the media in Mexico}

Because many newspapers in Mexico have a dedicated human rights beat, the relationship between the field of newspapers and the field of domestic human rights NGOs in Mexico is one of mutual dependency, though one in which human rights NGOs are subordinate. Journalists could consult other sources for human rights information, namely the governmental human rights commissions or international organizations - or they could decide to divert their reporting resources to other topics. Human rights defenders, on the other hand, have tended to see a presence in the news as absolutely essential to their work. As a result, and as part of an overall process of professionalization (Waisbord 2011), they have been developing and deploying information subsidies to encourage journalists' selection of their information as news.

My interviewees at Mexican human rights NGOs said that media coverage helps them to educate the public, to raise their profiles, and to generate a "bigger discussion." 3 "We don't have the resources," one interviewee said, "So our way of discussion is often through the printed press [and] some radio stations." Crucially, they explained, the media also supports their NGOs in the generation of public moral outrage. A mechanism for stirring this outrage is known in Mexico as the denuncia, which translates as "denunciation" - namely, a condemnation or an accusation levied publicly. This public aspect of the denuncia is all important, for, as one human rights defender put it, "When human rights problems are not really known, this favors impunity and permits repression." Exposing violations to "public opinion," however, places a check on human rights violators, as another informant described it, creating a "guarantee of protection" ${ }^{7}$ for targets and witnesses of violations. This is because the public moral pressure engendered by human rights reporting ideally will cause "an authority [...] to think twice before a repressive action because he is starting to feel he is under a gaze."

Human rights defenders said, however, that alone, their organizations could not generate the same "level of audience" as they could by working with the media. They therefore traditionally relied on the mainstream media as their "door... so that public opinion realizes what is happening." ${ }^{10}$ In a political context where considerable emphasis was put on at least the appearance of democracy, public opinion did matter. The media, as one interviewee put it, is "a space that counts a lot"11 for politicians, as it is politicians' gateway to publics as well. As one human rights reporter whimsically explained it: "Here we have a phrase: 'Authorities are like dogs. They only understand when they have been slapped by a newspaper." 12 It is no surprise, then, that interviewees described their relationships with journalists as an indispensable aspect of their strategies.

Human rights defenders did not speak of these relationships - and the news coverage issuing from them - as a matter of circumstance but rather as the product of strategic action. These strategies involve first understanding the journalistic logic, including news 
outlets' information values. For example, one NGO's training guide on "Communication and Visibility Strategies for Civil Society Organizations" states, "If we want our organization, our actions, or our words to be news, we have to consider certain basic norms that govern the genre" (Comunicación e Información de la Mujer AC 2004: 43). A second aspect of these strategies entails shaping NGO information - both in terms of content and in terms of source characteristics - to match these information values. By doing this, NGOs take on some of news outlets' costs in identifying, evaluating, and preparing information for publication; in other words, they provide "information subsidies" (Gandy 1982).

Returning to the notion of logics of the field, we can see information subsidies as a communication strategy designed to bridge two logics. Information subsidies convert the type of information valued by the communicator field into the type of information valued by the target audience field. Gandy posits that consumers, in the context of finite resources, are more likely to consume cheaper information (1982). We shall examine, in turn, two categories of information subsidies used by Mexican human rights NGOs: commercialized content and demonstrations of source credibility.

\section{Commercialized content as information subsidy}

Studies of the relationships between NGOs and the media have raised the concern that NGOs are subordinating their logics to journalistic logics in order to make the news. Of particular worry has been the nature of information subsidies that NGOs have provided to match the progressively more commercial information values of news outlets. For example, NGOs' information increasingly features celebrities, is timed to coincide with news events and is written with a personalized angle (Cottle and Nolan 2007; Fenton 2010; Waisbord 2011). According to this line of argument, which echoes a concern shared more widely in the literature addressing the commercialization of the media (e.g., Bourdieu 1998), this subordination can detract from NGOs' work. This occurs both through diverting NGO resources to media strategies and through diluting the norms at the heart of their logics, such as their impartiality and their commitment to "universal humanitarianism" (Cottle and Nolan 2007: 864; Fenton 2010).

At the time of my research, newspapers in Mexico were dealing with shrinking profits and growing competition, leading to the rise of a "spot news" model described by one editor as "very graphic; brief, clear, short articles in a simple language; direct; the most information in the least space" (quoted in McPherson 2012: 2305). Newspaper stands were also punctuated with what are known as nota roja publications, the term in Mexico for a popular variation on tabloid news about crime and violence that translates literally as "red news." In this context, the human rights defenders I interviewed in Mexico were indeed struggling with a perceived clash of logics between their field and the journalistic field. At times, they described this clash as manifested in fundamentally opposite information values; human rights work values lengthy tomes, while journalistic work values the pared news pyramid. As one human rights defender explained it, "It is not easy to translate your activity into a press article. How do you prioritize, have a title, hook the media? [Avoid] using 20,000 words when you can use one." ${ }^{13}$ Human rights work has a long-term optic, while journalistic work is topically volatile, in the view of another interviewee. Human rights rhetoric can be passionate, while journalistic language is usually dispassionate (Powers 2015a). One human rights defender 
illustrated this by describing a colleague's behavior at a press conference commemorating the Aguas Blancas massacre in Mexico:

Every time he spoke, the people turned off their tape recorders. "The fascism of the government...." - automatically the four reporters went to get a coffee, and we knew that these positions, they are not disposed to accept them. They need to have a more ordered discourse - less "Grrrrrrrr!" - so that they can describe something about you. You have to tone down certain discourses. ${ }^{14}$

Furthermore, the thematic foci of human rights information may also be at odds with what the media seeks. As one informant described it:

Human rights is hard to place in papers. It isn't nota roja. It isn't [always] accompanied by police brutality. It is more legal, ethical. So it is a little complicated for the media to sell this. ${ }^{15}$

The latter's use of commercial terminology was not isolated. In fact, my NGO informants spoke to me so frequently about their relationship with the media in terms of the selling of information, that I stopped one to ask, "Why do you use 'buy' and 'sell' as words [in your description]?" She replied:

The newspaper is a product... The newspaper is sold - it is supply and demand. The public [reads] the article that captures their attention — and unfortunately, these articles in some cases have to do with accidents, assaults. They are easier for the people to see and to buy. For the press, if the people are not interested, there is no sale, and if there is no sale, they say, "You know what, I won't write about this but instead about something else...." If readers are not interested, what do you do? ${ }^{16}$

Commerciality, then, was an information value perceived in the Mexican media by human rights defenders, and they tailored the content they targeted at journalists accordingly. In addition to seeking news pegs on which to hang their long-term research and shaping their information to fit journalistic expectations, some tended to target reporters with information about only certain types of violations, those that lend themselves to the "scandalous" and to "hard news." ${ }^{17}$ As one interviewee explained it:

At the end of the day, they are selling information, selling to editors and to the public. If the news is not red, yellow, spectacular, it is not news. If there are not deaths, wounded, corruption, information on a politician, it is not very attractive. ${ }^{18}$

These tactics, as well as human rights defenders' spontaneous usage of market terminology when discussing their relationships with the media, may indicate, as Cottle and Nolan (2007: 874) found with respect to international humanitarian aid agencies, the "institionaliz [ation]" and "normaliz[ation]" of commercial information values into NGO logics. This finding is troubling, particularly if it constricts pluralism by limiting the types of human rights violations for which subjects and witnesses can seek accountability through the media. That said, for those whose stories are covered, being in the news is one of the most effective strategies for pluralism in terms of being heard by wide audiences; furthermore, news coverage is just one of the range of advocacy strategies that NGOs employ and thus just one of a number of strategies for human rights pluralism (Powers 2015b, 2015c).

In any case, it is important to move beyond this finding for a number of reasons. First, this is just one trend at the meeting of two logics that, despite some dominant and shared characteristics, are overall quite diverse. This diversity ranges not only across each field but also within each institution, both at the section level and at the individual level (Orgad 2013; 
Waisbord 2011; Powers 2014; Wright 2016). Second, this is a trend about which NGOs, as the subordinate participant in the NGO-journalism relationship, can do little but lament at worst and be "pragmatic" at best (Waisbord 2011: 145). Bringing these two points together, we can move to investigating how alternative aspects of these complex logics might be informing other types of information subsidies - types that do not require NGOs to eclipse their values. The NGO communications strategy manual referenced above is guided by the question: "How can we be in the media without losing ourselves?" (Comunicación e Información de la Mujer AC 2004: 12). One answer is the provision of source credibility as an information subsidy to support journalists in the resource-intensive process of source verification.

\section{Source credibility as information subsidy}

Time and again, reporters, editors, and human rights defenders told me of the importance of credibility to their organizations' successes. Credibility, or the ability to be believed, is a reputational resource, namely as a type of symbolic capital that can be mobilized in the pursuit of power (Bourdieu 1993; Thompson 2000). Often, this occurs via the utilization of credibility for communication - an action that, without credibility, is nigh impossible; to communicate, as in to get one's message across, one must be believed. Credibility is also a relational resource created between the entity seeking credibility and the entity evaluating credibility (Hardin 2002). One can build credibility in a number of ways, including, as explored below in the case of Mexican human rights NGOs, via interpersonal relationships, via authority, and via networks. One can also damage one's credibility in these ways, or it can be destroyed through the propagation of discrediting discourses by one's opponents. As such, credibility, like other reputational resources, is precarious (Thompson 2000).

Because communication is at the core of both journalistic and human rights work, it is no surprise that actors in both fields value their credibility. Journalists need credibility with publics in order to maintain and build audiences as well as credibility with individuals such as sources (Waisbord 2006; Franklin and Carlson 2011; McPherson 2012). Human rights NGOs rely on credibility with publics to mobilize the moral outrage that underpins their "name and shame" methodology as well as credibility with individuals such as journalists, volunteers, and donors (Gibelman and Gelman 2004; Cottle and Nolan 2007; Brown 2008; Land 2009). This concern with credibility is reflected in the practices of journalists and human rights defenders to build and safeguard it. It is also shared across a variety of news outlets and NGOs studied around the world (see, e.g., Orentlicher 1990; Schlesinger 1990; Manning 2001; Hopgood 2006; Waisbord 2006; Fenton 2010; Franklin and Carlson 2011; Reich 2011). Each organization, however, also operates within particular contexts that have implications for building credibility. In the Mexican context, this includes "authoritarian enclaves" that persist in institutions and cultures, a legacy of the semi-authoritarian regime that governed for much of the twentieth century and whose party has returned to power today (Lawson 2000). In this section, I first outline this context before going on to detail the practices NGOs undertake to demonstrate source credibility as an information subsidy.

\section{The Mexican political context}

Human rights NGOs and newspapers were both instrumental to the slow political liberalization in Mexico leading to the 2000 election of the opposition. In the decades preceding this, 
a handful of journalists decided to break with the tradition of cozy cash-for-coverage relationships with government officials in order to found and revamp print publications dedicated to supporting democratization (Hughes 2006). These publications, and the emulators they sparked, discovered that looking to the market for revenue, rather than the state, was sustainable. This was in part due to audience - and thus advertiser - demand for information that critiqued the government and that included voices from civil society (Lawson 2002). These market-oriented newspapers were trying to recruit and retain audiences and advertisers well aware of their sector's history - and their peers' ongoing practice - of financial-informational contracts with government officials. Their journalists were thus concerned with building credibility with respect to incorruptibility and to independence; human rights coverage, which by its nature is critical of government officials, was one way to do this. Journalists' concern with credibility, however, also made them extremely careful about verifying the credibility of their sources, including those on the human rights beat (McPherson 2012).

The human rights beat consisted of governmental human rights commissions as well as the most "serious"19 (in interviewee journalists' words) of the human rights NGOs that flourished in Mexico starting in the early 1990s (Sikkink 1993; Acosta 1994; Aguayo Quezada and Parra Rosales 1997). Human rights defenders at these organizations were well versed in the power of credibility for communicating as media sources or otherwise - a kind of power that one interviewee referred to as "moral." 20 They were also repeatedly subject to discrediting discourses propagated by particular government officials who retaliated against accusations of violations by publicly accusing NGOs of financial and political corruption (see, e.g., Amnesty International 2001). I turn next to this contested but core aspect of human rights NGOs' logics and how we might conceptualize the related work that NGOs do to communicate across NGO and journalistic fields.

\section{Strategies for building source credibility}

Mexican human rights NGOs had developed practices for building source credibility because, as mentioned above, they knew that journalists valued it. Journalists' concern with their own credibility led them to worry about being tainted by association with discredited sources, particularly in the context of corrupt traditions in the journalistic and other fields. As such, journalists at Mexican newspapers took care to verify their sources' credibility. One editor explained verification to me using the example of a fictional NGO:

You have to first investigate the organization if it is not well-known and go to see that - if it is an organization that says that it helps drug-addicted children rehabilitate - you have to go see that there is a building with addicted children inside; that there are doctors, specialists, talking to the children; that you go and talk to a child who says, "I am here because I am addicted" this part is very important to investigate. (quoted in McPherson 2012: 2307) ${ }^{21}$

Obviously source verification makes significant demands on the resource of time, which was in short supply under the spot news model. Furthermore, verification's informational return might be zero should the evaluation yield a noncredible source. It makes sense, then, that human rights NGOs were employing strategies to build source credibility as a way to speed verification and thus to make their information cheaper for journalists. 
The strategies NGOs employ for building source credibility are oriented around relationships. These relationships, as explained below, are with journalists themselves or with authoritative individuals and networks that, because journalists already deem them credible, can provide credibility by association. Underpinning these relationships of credibility is credible performance over time. Namely, this includes a public performance in terms of a history of commitment to their causes and a reputation of truth telling as well as private performances within each relationship (Fenton 2010; Hopgood 2006; Orentlicher 1990).

\section{Interpersonal credibility with journalists}

The first strategy for boosting source credibility is to initiate personal relationships with sympathetic reporters, "getting them to know us," as one human rights defender put it, "by name and by face." 22 As the NGO communication strategy guide quoted earlier counsels:

First and foremost, no media is monolithic. All of them are made up of people, and in every human team surely we can find women and men to consider allies for breaking the circle, for [helping us] to enter the media. (Comunicación e Información de la Mujer AC 2004: 39)

Human rights defenders are therefore seeking reporters whose interpretations of the journalistic logic overlaps with their human rights NGO logics with respect to, as one interviewee put it, "journalism that helps the citizenship." 23 These defenders told me they actively invest in and "take advantage" of the "utility" 24 of these "personal relationships." ${ }^{25}$ A human rights defender explained it in the following way: "There is a rapprochement much at the level of friendship. We know each other personally, we live here - it is a small town." ${ }^{26}$

The utility of these personal relationships includes being the first port of call for reporters investigating a story, which is the strongest guarantee of getting published, a higher likelihood of attendance at press conferences and of phone calls from reporters catching up on conferences they miss, and insider knowledge of use to the NGOs. As one NGO spokesperson explained it:

We exchange information. Many times the reporters give you pieces of information on places you can't access, like the government, because the political class is very interested in them. They are also a source of information; we take good care of our relationship with them. ${ }^{27}$

These relationships - friendships, even — are ideally characterized by trust, credibility, and reciprocity. In terms of the latter, "They get elements for their articles," this NGO interviewee said, "And we have the possibility of positioning articles through advance information and their trust." ${ }^{28}$ In some cases, a natural affinity exists because human rights reporters have switched professions to become human rights defenders and vice versa. These individuals understand the logics of both fields, but, beyond this, they have social capital networks - in both fields and can serve as an interpersonal credibility bridge between the two types of institutions. As such, they can be extremely valuable for NGOs, as they become the conduit through which information, and the organizations themselves as sources, can enter the news.

\section{Credibility via authority}

A second NGO technique for shoring up source credibility is via institutionalized relationships with individuals who have authority through their positions as public figures in the human rights field, which in turn are based on performance and expertise. Human rights 
defenders at NGOs with these institutionalized relationships told me that these leaders are a draw for reporters; as one described it: "The media look for concrete people who have a trajectory in the topic and look for their opinion. They don't look for the opinion of the institution, but of a person." 29 As another human rights defender explained, this is not always the best way for media to get information, but they do it nonetheless:

They like famous names. They will ask for Don Miguel [Concha Malo, a ground breaker for human rights in Mexico] even if [our coordinator of education, promotion, and diffusion] knows more [on the topic in question]. And this is the criticism of the media - they don't give space to the young. Don Miguel is their point of reference. ${ }^{30}$

In other words, human rights NGOs populated by young workers (who, by inference, lack a history of credible performance) can harness the credible reputations of field leaders to get their information into the media - people who, as another human rights defender described them, "have a lot of credibility [and] moral authority." 31

\section{Credibility via networks}

In addition to building relationships with credible individuals, NGOs boost their credibility via association with other NGOs, particularly those with more established reputations. These may be informal, temporary associations or formal, permanent networks. An example of the former are the temporary alliances formed for the duration of a press conference between two or three smaller NGOs and the Human Rights Centre Fray Bartolomé de las Casas. This organization's communications coordinator described this sort of press conference: “The only organization that speaks is Fray Bartolomé, which has a certain respect [and] is recognized.... It is easier to [get the media to] listen to a very well-known voice than to try and position a new organization." 32

The formalized networks of NGOs are themselves administered by NGOs. For example, the National Network of Human Rights Civil Organisations for All Rights for All serves as an umbrella for dozens of human rights organizations in the majority of Mexico's states, ranging from big groups with paid staff to tiny volunteer groups, and from the "group always connected to the Internet to the one that has neither Internet nor electricity," 33 according to its executive secretary. Networks like this serve as a "bridge," 34 as one of their directors explained it, between the media and their member organizations, both in terms of information and in terms of credibility. Network headquarters develop interpersonal relationships of credibility with journalists. They feed these journalists the press releases of member organizations, invite them to large press conferences they organize on behalf of their members and respond to their requests for information on a particular issue by connecting them with experts in their membership. A human rights worker at one of these networks described her role accordingly: "Visibility services is what we do - bringing social movements and the media closer together." ${ }^{35}$ As such, networks are valuable to both groups. They allow the smallest NGOs to gain source credibility by association with the more prominent NGOs that already possess it. These networks also mitigate reporters' need to fully engage in the time-consuming process of source verification, since organizations already deemed credible by these reporters are vouching for untested NGOs.

These strategies for building source credibility are not usually an end in themselves but rather a means to building credibility with the publics and policy makers who are often the targets of human rights advocacy. As Gandy (1982) and Carlson and Franklin (2011) point 
out, appearing in the media implies a sort of credibility endorsement. It is therefore a verification subsidy for target audiences, in that these audiences can assume that the media has undertaken an evaluation of the source's credibility on their behalf; journalists are thus the gatekeepers to public credibility as well as to the public sphere. It is to the implications of NGOs' verification subsidies for pluralism and accountability in the public sphere that I turn to next.

\section{Implications for pluralism and accountability in the public sphere}

To understand the implications of information subsidies based on source credibility for pluralism and accountability, we must return to the connection, underscored by the concept of information subsidies, between resources and voice. It is useful to recall Bourdieu's (1986) point that different forms of capital are convertible. The verification subsidies outlined here depend in part on symbolic capital (a reputation of credibility), on cultural capital (knowledge about building credibility and about effective communication strategies), and on social capital (relationships). These in turn depend on other resources; economic capital, for example, can determine the extent of cultural capital an NGO has in terms of media literacy amongst its staff. Human rights NGOs vary among each other and in comparison with other categories of sources in their distribution of these resources. This distribution has an impact on pluralism in the public sphere, but this too varies according to what kind of pluralism we mean: namely, pluralism vis-à-vis the field of power; pluralism within the field of human rights NGOs; and pluralism of access to human rights accountability.

As a field competing with the field of power for column inches, demonstrating credibility plays to human rights NGOs' strengths in terms of the forms of capital that dominate their fields. Building credibility through relationship with journalists, authoritative individuals, and networks of NGOs requires NGOs to deploy social capital, which they are strong on due to the centrality of solidarity and networking in NGO logics (Keck and Sikkink 1998; Atack 1999; McLagan 2006; Dütting and Sogge 2010). Credibility and networks of solidarity allow NGOs to punch above their weight in terms of presence in the public sphere - if that weight is measured purely by the economic and political capital that are the dominant currencies of power in many societies (Lehmann and Bebbington 1998). They also equip NGOs to take on hostile contenders, such as the retaliatory government officials mentioned above (Aguayo Quezada and Parra Rosales 1997). The verification subsidies outlined in this article thus boost pluralism if we define it as the presence of alternative and critical voices in the public sphere - though, granted, NGO voices are not always alternative and critical (Powers 2016a).

This does not mean, however, that NGOs are equal contenders with the political-economic elite for journalists' attention, nor does it mean that this visibility is shared equally between all NGOs (Waisbord 2006; Fenton 2010; Thrall, Stecula, and Sweet 2014; Powers 2016b). If we look at pluralism of voice within the human rights NGO field, we see that the uneven distribution of resources allows some NGOs much more voice than their poorer peers. Even if hierarchy is deemphasized within NGO networks (Sikkink 1993), it is a strong organizing principle in journalists' relationship with the constituents of the human rights NGO field. This "hierarchy of credibility" (Becker 1967) is a product of limits on journalists' time to evaluate new sources and NGOs' differential abilities to provide information subsidies. As one human rights reporter explained it to me: "There are a lot of sources, but we 
don't know them or use them, or they don't approach us - or they don't know how to approach us. [So,] there are reactions of silence to their work." ${ }^{36}$ Thus, many human rights NGOs lack the capital - whether cultural, social, symbolic, or economic - to know how to and to be able to build bridges to the journalistic field. As a human rights worker described it:

It is not just because they [human rights NGOs] are nice that their topics come out in the media. It has to do with this - that they understand, that they have a media strategy, that they have invested time and economic resources. There are others for whom this is more difficult, and I see there the problem of economic sustainability. Being in a media is not an accident, not luck - but rather that you construct [a strategy] and maybe hire someone, or give a press conference. It is not easy to finance it. ${ }^{37}$

The ability to demonstrate source credibility, then, like all information subsidies, maps onto the distribution of resources within a field as well as across fields. They thus restrict the pluralism of voice within the NGO field, and there is only so much that the solidarity of networks can do to overcome this. For example, a communications officer at an NGO network for the rights of children told me, "It has happened that we channeled certain organizations to newspapers and they [the journalists] call us [afterwards] and say, 'No more with them! That organization does not have the technical abilities to do the interview." 38

Though important, thinking about pluralism of voice in terms of NGOs' voices, whether vis-à-vis the field of power or within the human rights NGO field, is not the most important type of pluralism in human rights communication. Instead, the pluralism that should most concern us is the pluralism of access to the accountability mechanism of human rights for those who have been subjects of human rights violations. This accountability mechanism has several methodologies and several players, but those relevant here are the work of NGOs, via the media, towards "publicly 'naming and shaming' abusive governments," as Human Rights Watch (2013) describes it. Even if the centrality of credibility in media and NGO logics keeps poorer NGOs out of the news as sources, the solidarity and networking aspects of the NGO logic can help the content of their information - and thus the subjects and witnesses of violations they represent - get coverage. So it may be that these smaller NGOs do not themselves get voice, but the subjects and witnesses of violations they have investigated do if the larger NGOs take up smaller NGOs' information about their cases. Whether or not they do this depends on a variety of factors. This includes the cases' alignment with the goals of the larger NGO, as illustrated by one human rights defender's reasons for uploading the press releases of less digitally literate NGOs to her NGO's website: "It is an act of solidarity, to reinforce the work in certain topics that are strategic for us - like economic, social and cultural rights, labour, torture." ${ }^{39}$ Another factor is the credibility of the smaller NGO and ultimately the credibility of the subject or witness of the human rights violation; it is a given that credibility evaluations occur at each point along the human rights communication chain - and that resources matter every time.

\section{Conclusion}

By shedding light on source strategies - and not just powerful sources, but rather the competitive and collaborative activities of a field that tends to critique the field of power-this article has helped redress the imbalance of the sociology of journalism, which has been 
weighted towards journalists over their essential collaborators - their sources (Gandy 1982; Schlesinger 1990). Furthermore, a productive by-product of showing how subordinate sources build information subsidies has been rescuing the concept from the pejorative meaning it has come to carry through its association with powerful sources. I have shown it to be an analytically useful tool for understanding and assessing strategies that have the potential to boost pluralism and accountability in the public sphere.

Another critique of information subsidies, present in the literature on NGO journalism, is their association with "selling out" to commercial media. Indeed, as seen in the case of featured Mexican human rights NGOs, journalistic logics can significantly shape the information that human rights defenders proffer to the news cycle. In this case, it is clear that the subjects and witnesses of non-gory, slow-burn human rights violations (like violations of economic, social, and cultural rights) are more likely to be omitted from access to the public sphere - at least via newspapers. Still, this omission should be seen in the whole picture of the advocacy activities that human rights defenders deploy, in which communicating with the mainstream media plays an important but not exclusive role. Furthermore, these other activities and the logics that drive them may be actively distinguished and shielded from the commercial aspects of journalistic logics.

Though information subsidies in the form of commercialized content can be deleterious for certain categories of voice (though beneficial for others), this does not mean that we should tar all information subsidies with the same brush. Information subsidies may very well be an inescapable aspect of successful communication and therefore pluralism. Any time an actor tries to communicate outside of her field, she increases the likelihood she will be heard if she tailors her communication to the information values of her target audience. As we have seen with Mexican human rights NGOs' development of source credibility as information subsidy, deploying information subsidies can be a matter of capitalizing on rather than capitulating one's own information values. The ability to effectively do so, however, depends on one's resources, and so information subsidies cannot escape entirely their stratification effect on pluralism. This was evident in the distribution of credibility among human rights sources as perceived by journalists. Indeed, the symbolic capital of credibility may play a more important role in source selection and in the pluralism of attention and voice as a whole than it has been given credit for in the media sociology literature to date.

In sum, in this article, we have seen how the centrality of credibility for both human rights NGOs and news outlets' logic allows NGOs to use their strengths for creating information subsidies. Through demonstrating their credibility as sources, NGOs speed up journalists' verification practices. This reduces the cost of these NGOs' information to journalists and thus facilitates its entry into the public sphere. These information subsidies, rooted in a performed credibility across time, are transmitted via the social capital in networked relationships of solidarity between NGOs and journalists, between NGOs and human rights figureheads, and among NGOs. Overall, we see that this type of information subsidy holds promise for pluralism in the public sphere for the human rights field vis-à-vis the field of power and for the pluralism of access to the accountability mechanism of human rights even if the dimensions of credibility that make it a form of capital mean that a "hierarchy of credibility" (Becker 1967) exists within the human rights field with respect to individual NGOs' attempts to build informational bridges to the media field.

This does not mean, however, that recommending that NGOs invest in the verification subsidies outlined in this article is unproblematic. First of all, while credibility is a strength 
for NGOs, it is also their Achilles' heel. Compared to other sectors of society, NGOs are particularly vulnerable to discrediting discourses (Gibelman and Gelman 2004). This is because their relative dearth of economic resources mean that they trade predominantly on their symbolic and social capital (Brysk 1994). Furthermore, because of the networks of associations that run through civil society, an accusation of corruption against one NGO can taint many more (Global Policy Forum 2012). Repairing a damaged reputation of credibility can divert precious resources from NGOs' core missions (Cottle and Nolan 2007; Brown 2008).

Second of all, recommending that NGOs be strategic about their communication practices is akin to condoning the professionalization of the NGO sector - a trend also critiqued for diverting resources from the operational and ethical cores of NGO logics (Cottle and Nolan 2007). While I agree with this critique, the fact of the matter is that the dynamics of the journalistic field, to which the human rights NGO field is subordinate in the news-making relationship, increasingly require this of sources. The practical implication of this critique for NGOs is that they withdraw from the melee in disdain which is self-defeating, not only for each NGO's purposes but also for the wider societal goals of pluralism and accountability. Given limited resources, NGOs inevitably will face decisions about which types of information subsidies to prioritize. It may make sense to prioritize investing in source-credibility information subsidies - and not just because, unlike commercialized-content information subsidies, they do not threaten NGOs' logics. This is also because my evidence indicates that source credibility is a journalist's first hurdle for the assessment of newsworthiness (McPherson 2012). Investing in content information subsidies without suitably investing in demonstrations of source credibility may therefore be ineffective.

The case developed in this article is specifically about a number of Mexican human rights NGOs. As mentioned above, human rights and journalistic fields' concerns with credibility have been documented in a variety of cases, and this argument would therefore benefit from being tested in other settings. Still, its theoretical focus on credibility and communication in the public sphere may shed light on the broader context of political transition in Mexico and elsewhere. Transitions from authoritarian rule tend to be characterized by the liberalizing of the state, which widens access to rights and to the public sphere - often conciliatory gestures in a misguided attempt to hold onto power. An explosion of civil society rushes in to fill this space, including human rights organizations and news outlets (O'Donnell and Schmitter 2013). We can also understand this transition of a state that quashes dissenters to one that tolerates them as a transition from a monopoly on public credibility to its decentralization. From this perspective, the keen concern with credibility we saw among Mexican human rights defenders and journalists may reflect not only the general importance of credibility to advocacy and journalism. It may also be part and parcel of a scramble for the previously inaccessible and precious resource of public credibility. Thinking about how public credibility is distributed and denied - via, for example, the discrediting discourses about human rights organizations propagated by some Mexican government officials - highlights another dimension of the dynamics of political transition. The credibility behind the communications of civil society actors may have significant impacts on transitions, such as the spread of the human rights "justice cascade" in Latin America (Lutz and Sikkink 2001).

Furthermore, thinking about the communicators and recipients of information as having information logics - logics whose differences can be addressed via information subsidies 
that are correlated with resources - also benefits future research about communicating across field boundaries. This framework yields insight on the potential of digital direct-tocitizen communications, a significant trend in today's human rights communication, for pluralism and accountability in the public sphere. Earlier research indicates that resources may matter even more when online communication enters the NGO toolkit (Fenton 2010; Thrall, Stecula, and Sweet 2014). Without the credibility endorsement that comes with being a mainstream media source, we can imagine that human rights NGOs need to build up credibility directly with audiences. This may prove more difficult, as audiences do not all belong to the same field and are, therefore, located and motivated differentially. It may well be that understanding communication as facilitated by the information subsidy of source credibility will reveal yet another way in which digital technologies do not level the communications playing field.

\section{Notes}

1. The empirical findings in this article form part of the media ethnography I conducted of human rights reporting in Mexico in 2006. For several months, I shadowed the human rights beat at two of Mexico's highest-circulation newspapers, La Jornada and El Universal. In addition to this participant observation of newsrooms and of journalist-source interactions, I collected artifacts and conducted 26 in-depth, semi-structured interviews with human rights reporters and 26 further interviews with their editors at national and regional newspapers. I also interviewed 18 human rights defenders assigned communication roles at their organizations, which included local and national NGOs, umbrella NGOs that served to network NGOs across the country, and government human rights commissions. The information in this article is largely based on the latter interviews. In general, my interview guides covered the following: how interviewees saw their workplaces, their collaborators and competitors, and their roles; how they understood human rights and human rights newsworthiness; what influenced the decisions they made about human rights information and what these decisions were; what conflicts they faced and how they faced them; and what had happened in the past and what they expected of the future with respect to this sort of reporting. Interviewees were all offered anonymity, and though most elected nonanonymous interviews, I have chosen in most cases to preserve their anonymity. I transcribed and translated these interviews and conducted thematic analysis on them as well as on my field notes and the artifacts.

2. Verification subsidies exist in a variety of forms; another type highly relevant to the use of digital reports from civilian witnesses in human rights fact finding is the inclusion of metadata with these reports. This refers to data about this information - such as time, place, and source of production - that facilitate the information's corroboration (McPherson 2015b).

3. Interview date: August 2, 2006.

4. Interview date: August 2, 2006.

5. Interview date: July 4, 2006.

6. Interview date: July 5, 2006.

7. Interview date: August 2, 2006.

8. Interview date: July 4, 2006.

9. Interview date: July 5, 2006 .

10. Interview date: July 5, 2006.

11. Interview date: July 31, 2006.

12. Interview date: July $12,2006$.

13. Interview date: July 5, 2006.

14. Interview date: July 13, 2006.

15. Interview date: July $31,2006$.

16. Interview date: July 5, 2006. 
17. Interview date: July 4, 2006.

18. Interview date: July 31, 2006.

19. Interview date: May 14, 2006.

20. Interview date: July 13, 2006.

21. Interview date: June 26, 2006.

22. Interview date: July 5, 2006.

23. Interview date: July 31, 2006.

24. Interview date: July 4, 2006.

25. Interview date: July 5, 2006.

26. Interview date: July 31, 2006.

27. Interview date: July 31, 2006.

28. Interview date: July 31, 2006.

29. Interview date: July 4, 2006.

30. Interview date: August 2, 2006.

31. Interview date: July 4, 2006.

32. Interview date: July $31,2006$.

33. Interview date: July 4, 2006.

34. Interview date: July 13, 2006.

35. Interview date: July 13, 2006.

36. Interview date: June 22, 2006.

37. Interview date: July 11, 2006.

38. Interview date: July 5, 2006.

39. Interview date: August 2, 2006.

\section{Funding}

This work was supported by the Economic and Social Research Council (Grant no. ES/K009850/1), the Isaac Newton Trust, and the Gates Cambridge Trust.

\section{Notes on contributor}

Ella McPherson is Lecturer in the Sociology of New Media and Digital Technology at the University of Cambridge, as well as the Anthony L. Lyster Fellow in Sociology at Queens' College and a Research Associate of the Centre of Governance and Human Rights. Her current research is on the use of social media at human rights NGOs, focusing on the construction of knowledge in the digital age, and her previous research was on human rights reporting at Mexican newspapers, which examined the contest for public credibility among state, media, and NGO actors underpinning human rights coverage.

\section{References}

ACOSTA, Mariclaire. (1994, July 17) El Sexenio Salinista y los derechos humanos. Reforma, Enfoque 14.

AGUAYO QUEZADA, Sergio, and PARRA ROSALES, Luz Paula. (1997) Las Organizaciones No Gubernamentales de Derechos Humanos en México: Entre La Democracia Participativa y La Electoral (Mexico City, DF: Academia Mexicana de Derechos Humanos).

AMNESTY INTERNATIONAL. (2001, December 10) Mexico: Daring to raise their voices. [Online]. Available: https://www.amnesty.org/en/documents/amr41/040/2001/en/ [2 May 2016].

ATACK, Iain. (1999) Four criteria of development NGO legitimacy. World Development, 27(5), 855864.

BECKER, Howard S. (1967) Whose side are we on? Social Problems, 14(3), 239-247.

BOURDIEU, Pierre. (1983) The field of cultural production, or: The economic world reversed. Poetics, 12(4-5): 311-356. 
BOURDIEU, Pierre. (1986) The forms of capital. In Handbook of Theory and Research for the Sociology of Education, John E. Richardson (ed.) (New York: Greenwood Press).

BOURDIEU, Pierre. (1993) The Field of Cultural Production: Essays on Art and Literature (New York: Columbia University Press).

BOURDIEU, Pierre. (1998) On Television (New York: The New Press).

BROWN, L. David. (2008) Creating Credibility (Sterling, VA: Kumarian Press, Inc.).

BRYSK, Alison. (1994) The Politics of Human Rights in Argentina: Protest, Change, and Democratization (Stanford, CA: Stanford University Press).

CARLSON, Matt, and FRANKLIN, Bob. (2011) Introduction. In Journalists, Sources, and Credibility, Bob Franklin, and Matt Carlson (eds.) (New York: Routledge).

COMUNICACIÓN E INFORMACIÓN DE LA MUJER AC. (2004) Estrategias de Comunicación Y Visibilidad Para Las Organizaciones de La Sociedad Civil (Mexico City, DF: Comunicación e Información de la Mujer AC).

COTTLE, Simon, and NOLAN, David. (2007) Global humanitarianism and the changing aid-media field: Everyone was dying for footage. Journalism Studies, 8(6), 862-878.

DÜTTING, Gisela, and SOGGE, David. (2010) Building safety nets in the global politic: NGO collaboration for solidarity and sustainability. Development, 53(3), 350-355.

FENTON, Natalie. (2010) NGOs, new media and the mainstream news: News from everywhere. In New Media, Old News: Journalism \& Democracy in the Digital Age, Natalie Fenton (ed.) (London: Sage Publications Ltd.).

FRANKLIN, Bob, and CARLSON, Matt. (eds.). (2011) Journalists, Sources, and Credibility: New Perspectives (New York: Routledge).

GANDY, Oscar H. (1982) Beyond Agenda Setting: Information Subsidies and Public Policy (Norwood, NJ: Ablex).

GIBELMAN, Margaret, and GELMAN, Sheldon R. (2004) A loss of credibility: Patterns of wrongdoing among nongovernmental organizations. Voluntas: International Journal of Voluntary and Nonprofit Organizations, 15(4), 355-381.

GLOBAL POLICY FORUM. (2012) Credibility and legitimacy of NGOs. Global Policy Forum. [Online]. Available: https://www.globalpolicy.org/ngos/introduction/credibility-and-legitimacy. html [2 May 2016].

HARDIN, Russell. (2002) Trust and Trustworthiness (New York: Russell Sage Foundation).

HOPGOOD, Stephen. (2006) Keepers of the Flame: Understanding Amnesty International (Ithaca, NY: Cornell University Press).

HUGHES, Sallie. (2006) Newsrooms in Conflict: Journalism and the Democratization of Mexico (Pittsburgh, PA: University of Pittsburgh Press).

HUMAN RIGHTS WATCH. (2013) Our History. [Online]. Available: http://www.hrw.org/node/ 75134 [2 May 2016].

KECK, Margaret E., and SIKKINK, Kathryn. (1998) Activists Beyond Borders: Advocacy Networks in International Politics (Ithaca, NY: Cornell University Press).

LAND, Molly. (2009) Networked activism. Harvard Human Rights Journal, 22(2), 205-243.

LAWSON, Chappell. (2000) Mexico's unfinished transition: Democratization and authoritarian enclaves in Mexico. Mexican Studies / Estudios Mexicanos, 16(2), 267-287.

LAWSON, Chappell. (2002) Building the Fourth Estate: Democratization and the Rise of a Free Press in Mexico (Berkeley, CA: University of California Press).

LEHMANN, David, and BEBBINGTON, Anthony. (1998) NGOs, the state and the development process: The dilemmas of institutionalization. In The Changing Role of the State in Latin America, Menno Vellinga (ed.) (Boulder, CO: Westview Press).

LUTZ, Ellen, and SIKKINK, Kathryn. (2001) The justice cascade: The evolution and impact of foreign human rights trials in Latin America. Chicago Journal of International Law, 2(1), 1-33.

MANNING, Paul. (2001) News and News Sources: A Critical Introduction (London: Sage Publications).

MCLAGAN, Meg. (2006) Introduction: Making human rights claims public. American Anthropologist, 108(1), 191-195. 
MCPHERSON, Ella. (2012) Spot news versus reportage: Newspaper models, the distribution of newsroom credibility, and implications for democratic journalism in Mexico. International Journal of Communication, 6, 2301-2317.

MCPHERSON, Ella. (2015a) Advocacy organizations' evaluation of social media information for NGO journalism: The evidence and engagement models. American Behavioral Scientist, 59(1), $124-148$.

MCPHERSON, Ella. (2015b) Digital human rights reporting by civilian witnesses: Surmounting the verification barrier. In Produsing Theory in a Digital World 2.0: The Intersection of Audiences and Production in Contemporary Theory, Rebecca Ann Lind (ed.) (New York: Peter Lang Publishing).

O'DONNELL, Guillermo, and SCHMITTER, Philippe C. (2013) Transitions from Authoritarian Rule: Tentative Conclusions about Uncertain Democracies, new edition (Baltimore, MD: Johns Hopkins University Press).

ORENTLICHER, Diane F. (1990) Bearing witness: The art and science of human rights fact-finding. Harvard Human Rights Journal, 3, 83-136.

ORGAD, Shani. (2013) Visualizers of solidarity: Organizational politics in humanitarian and international development NGOs. Visual Communication, 12(3), 295-314.

POWERS, Matthew. (2014) The structural organization of NGO publicity work: Explaining divergent publicity strategies at humanitarian and human rights organizations. International Journal of Communication, 8, 90-107.

POWERS, Matthew. (2015a) Contemporary NGO-journalist relations: Reviewing and evaluating an emergent area of research. Sociology Compass, 9(6), 427-437.

POWERS, Matthew. (2015b) NGOs as journalistic entities: The possibilities, promises and limits of boundary crossing. In Boundaries of Journalism: Professionalism, Practices and Participation, Matt Carlson, and Seth C. Lewis (eds.) (Abingdon, UK: Routledge).

POWERS, Matthew. (2015c) The new boots on the ground: NGOs in the changing landscape of international news. Journalism. Advance online publication. doi:10.1177/1464884914568077.

POWERS, Matthew. (2016a) Beyond boon or bane: Using normative theories to evaluate the newsmaking efforts of NGOs. Journalism Studies. Advance online publication. doi:10.1080/ 1461670X.2015.1124733.

POWERS, Matthew. (2016b) Opening the news gates? Humanitarian and human rights NGOs in the US news media, 1990-2010. Media, Culture \& Society, 38(3), 315-331.

REICH, Zvi. (2011) Source credibility and journalism: Between visceral and discretional judgment. Journalism Practice, 5(1), 51-67.

SCHLESINGER, Philip. (1990) Rethinking the sociology of journalism: Source strategies and the limits of media-centrism. In Public Communication: The New Imperatives, Marjorie Ferguson (ed.) (London: Sage Publications).

SIKKINK, Kathryn. (1993) Human rights, principled issue-networks, and sovereignty in Latin America. International Organization, 47(3), 411-441.

THOMPSON, John B. (2000) Political Scandal: Power and Visibility in the Media Age (Cambridge, UK: Polity Press).

THOMPSON, John B. (2010) Merchants of Culture (Cambridge, UK: Polity).

THRALL, A. Trevor, STECULA, Dominik, and SWEET, Diana. (2014) May we have your attention please? Human-rights NGOs and the problem of global communication. The International Journal of Press/Politics, 19(2), 135-159.

WAISBORD, Silvio. (2006) In journalism we trust? Credibility and fragmented journalism in Latin America. In Mass Media and Political Communication in New Democracies, Katrin Voltmer (ed.) (London: Routledge).

WAISBORD, Silvio. (2011) Can NGOs change the news? International Journal of Communication, 5, 142-165.

WRIGHT, Kate. (2015) “These grey areas," How and why freelance work blurs INGOs and news organizations. Journalism Studies. Advance online publication. doi:10.1080/1461670X.2015. 1036904 .

WRIGHT, Kate. (2016) Moral economies: Interrogating the interactions of nongovernmental organizations, journalists, and freelancers. International Journal of Communication, 10, 1510-1529. 